\title{
Traditional eye medicine use among patients with corneal disease in rural Malawi
}

\author{
Paul Courtright, Susan Lewallen, Steve Kanjaloti, Dighton J Divala
}

\begin{abstract}
Over a 15 month period all patients with corneal ulcers presenting at two district hospitals were interviewed regarding demographic and clinical characteristics and their use of traditional eye medicines (TEM). Of the 583 patients interviewed, $33.8 \%$ reported using TEM. There were no age or sex differences in TEM use. Patients who reported TEM use took, on average, 51 days between onset of symptoms and presentation while patients who denied TEM use took 13 days. Sixteen per cent of TEM users had a vision in the affected eye of $<3 / 60$ on presentation compared with $5 \%$ of non-TEM users. The frequent use of TEM and the presence of numerous traditional healers in rural areas of Africa suggest that eye care programmes could benefit greatly by including traditional healers in primary eye care activities.
\end{abstract}

(Br F Ophthalmol 1994; 78: 810-812)

There are few published reports of the contribution of traditional eye medicines (TEM) to the development of corneal disease in Africa although it is commonly recognised by clinicians to be a significant contributor to corneal ulceration, scarring, and blindness. ' In a study of 130 Tanzanian children presenting to a tertiary facility $14 \%$ of the corneal ulcers were related to TEM use. $^{2}$ A recent 1 year study of 103 patients attending the same tertiary hospital in Tanzania demonstrated that $25 \%$ of corneal ulcers were associated with the use of TEM. ${ }^{3}$ Similar findings have also been reported from Nigeria. ${ }^{4}$ In Malawi, a survey in 1976 of children in blind schools suggested that $26 \%$ of the children had associated TEM use. ${ }^{5}$ Patients who attend tertiary eye care facilities generally have severe eye pathology; there are no reports of corneal disease, TEM use, and vision loss among patients presenting to rural district hospitals. We sought to characterise patients who presented with corneal disease according to their use of TEM and to determine their treatment hierarchies before presentation at district hospital eye care facilities.

Mulanje District Hospital, Mulanje, Malawi

D J Divala

Correspondence to: Dr P Courtright, Internationa Centre for Eye Health, Bath Street, London EC1V 9EL.

Accepted for publication 1 June 1994
From January 1992 to March 1993 all patients was visible (by torch, no slit-lamp was available), who presented to ophthalmic medical assistants with corneal lesions in which fluorescein stain at two district hospitals (Mulanje and Chikwawa) in Malawi, were interviewed. All information was recorded on a standardised, pretested form. The interview form assessed treatment hierarchy for the eye disease episode: first treatment sought, whether this treatment was helpful, and follow up treatment. Care was taken to confirm histories by subsequent questioning; TEM use was considered positive if used as a primary or secondary treatment within the preceding month. Patients were often seen only once at the district hospital; we have no follow up information.

For one district (Chikwawa) we also calculated the ratio of corneal disease per 10000 population.

\section{Results}

During the study period 583 patients with corneal disease presented to the two district ophthalmic medical assistants; $197(33.8 \%)$ patients reported using TEM during the current eye disease episode. There was little difference in the age and sex distribution of patients reporting TEM use compared with those who did not (Table 1). Patients who reported TEM use took longer (mean 50.7 (SD 35.3) days) to reach the district hospital than patients who did not report TEM use (mean 12.9 (SD 17.8) days) $(\mathrm{p}<0.001)$. Patients who reported TEM use were more likely to have bilateral disease and poor vision on presentation (Table 2). One hundred and ninety four (33.3\%) patients had consulted a traditional healer at least once before presentation at the district hospital (113 as first source and 81 as second source). Treatment received from the healers was perceived to be equally helpful $(41 \cdot 6 \%)$ as that received from health centres $(42 \cdot 8 \%)$. Of the 173 patients who attended a health centre first, $59(34 \cdot 1 \%)$ went to a traditional healer for subsequent care.

In Chikwawa District $45 \cdot 7 \%$ of the patients came from the two subdistricts (Kasisi and Katunga) nearest to the district hospital although these two subdistricts account for only $10.8 \%$ of the district's population (Table 3 and Fig 1). Patients living close to the district hospital presented earlier and were less likely to report the use of TEM (Table 4). The use of TEM remained associated with late presentation of ulcers regardless of whether the patients came from the two nearby subdistricts $(9 \cdot 6$ days for non-TEM users and 23.8 days for TEM users) or from the more 
Table 1 Traditional eye medicine (TEM) use in patients with cormeal disease according to demographic and clinical characteristics

\begin{tabular}{|c|c|c|}
\hline & $\begin{array}{l}\text { TEM use } \\
\text { reported } \\
\text { (total 197) } \\
\text { No }(\%) \\
\end{array}$ & $\begin{array}{l}\text { TEM use not } \\
\text { reported } \\
\text { (total } 386) \\
\text { No }(\%)\end{array}$ \\
\hline $\begin{array}{l}\text { Sex: } \\
\text { Males } \\
\text { Females }\end{array}$ & $\begin{array}{r}102(51 \cdot 8) \\
95(48 \cdot 2)\end{array}$ & $\begin{array}{l}224(58 \cdot 0) \\
162(42 \cdot 0)\end{array}$ \\
\hline $\begin{array}{l}\text { Age group (years) } \\
0-9 \\
10-29 \\
30-49 \\
50+\end{array}$ & $\begin{array}{l}24(12 \cdot 2) \\
81(41 \cdot 1) \\
64(32 \cdot 5) \\
26(13 \cdot 2)\end{array}$ & $\begin{array}{r}46(11 \cdot 9) \\
164(42 \cdot 6) \\
118(30 \cdot 6) \\
57(14 \cdot 8)\end{array}$ \\
\hline $\begin{array}{l}\text { Ocular injury: } \\
\text { Reported } \\
\text { Not reported }\end{array}$ & $\begin{array}{r}75(38 \cdot 3) \\
121(61 \cdot 7)\end{array}$ & $\begin{array}{l}120(32 \cdot 6) \\
248(67 \cdot 4)\end{array}$ \\
\hline $\begin{array}{c}\text { Number of days } \\
<7 \text { days } \\
7-13 \text { days } \\
14-20 \text { days } \\
21-27 \text { days } \\
28+\text { days }\end{array}$ & $\begin{array}{l}\text { ptom: } \\
10(5 \cdot 1) \\
13(6 \cdot 6) \\
25(12 \cdot 7) \\
22(11 \cdot 2) \\
127(64 \cdot 5)\end{array}$ & $\begin{array}{l}141(36 \cdot 6)^{\star} \\
115(29 \cdot 9) \\
58(15 \cdot 1) \\
36(9 \cdot 4) \\
35(9 \cdot 1)\end{array}$ \\
\hline $\begin{array}{l}\text { Corneal ulcer: } \\
\text { Uniocular } \\
\text { Binocular }\end{array}$ & $\begin{array}{r}137(69 \cdot 5) \\
60(30 \cdot 5)\end{array}$ & $\begin{array}{c}323(83 \cdot 7)^{\star} \\
63(16 \cdot 3)\end{array}$ \\
\hline $\begin{array}{l}\text { Symptoms report } \\
\text { Pain } \\
\text { Itching } \\
\text { Redness } \\
\text { Discharge }\end{array}$ & $\begin{array}{r}177(89 \cdot 8) \\
53(26 \cdot 9) \\
188(95 \cdot 4) \\
24(12 \cdot 2)\end{array}$ & $\begin{array}{r}363(94 \cdot 0) \\
63(16 \cdot 3) \\
371(96 \cdot 1) \\
57(14 \cdot 8)\end{array}$ \\
\hline $\begin{array}{l}\text { Referred by ophth } \\
\text { Referred } \\
\text { Not referred }\end{array}$ & $\begin{array}{l}1 \text { assistant to t } \\
21(10 \cdot 7) \\
176(89 \cdot 3)\end{array}$ & $\begin{array}{c}\text { ary hospital: } \\
15(3 \cdot 9)^{\star} \\
371(96 \cdot 1)\end{array}$ \\
\hline $\begin{array}{l}\text { Western medicine } \\
\text { Reported } \\
\text { Not reported }\end{array}$ & $\begin{array}{l}\text { presentation: } \\
141(71 \cdot 9) \\
55(28 \cdot 1)\end{array}$ & $\begin{array}{l}70(18 \cdot 1)^{\star} \\
316(81 \cdot 9)\end{array}$ \\
\hline
\end{tabular}

${ }^{\star}$ Differences are statistically significant at $\mathrm{p}<0.001$.

\section{Chikwawa District}

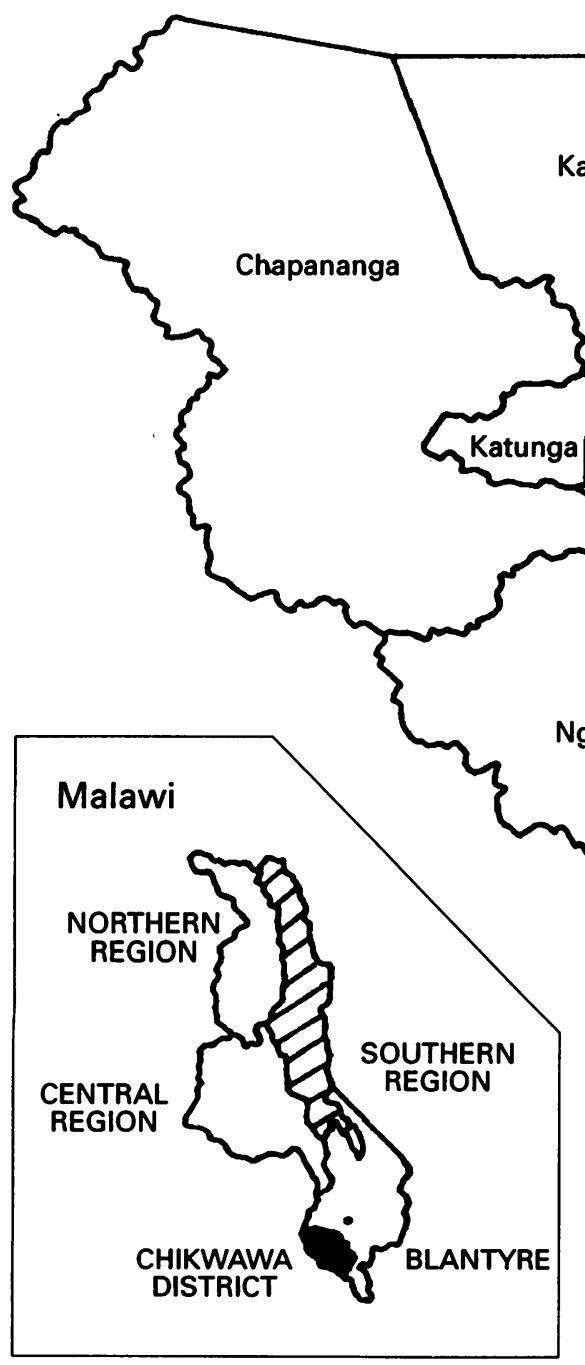

Figure 1 Location of study site (Chikwawa District). Chikwawa District Hospital (O), the main trading centres $(\bigcirc)$, and the main road (-- ) are marked.
Table 2 Visual acuity (by eye ${ }^{\star}$ ) in patients with corneal disease according to use of traditional eye medicines (TEM)

\begin{tabular}{lcl}
\hline & $\begin{array}{l}\text { TEM use } \\
\text { reported } \\
\text { Vision at presentation }\end{array}$ & $\begin{array}{l}\text { TEM use not } \\
\text { reported } \\
\text { No }(\%)\end{array}$ \\
\hline$>6 / 18$ & $59(24 \cdot 1)$ & $191(46 \cdot 5) \dagger$ \\
$6 / 18-6 / 60$ & $135(55 \cdot 1)$ & $191(46 \cdot 5)$ \\
$5 / 60-3 / 60$ & $11(4 \cdot 5)$ & $10(2 \cdot 4)$ \\
$<3 / 60$ & $40(16 \cdot 3)$ & $19(4 \cdot 6)$ \\
\hline
\end{tabular}

* Visual data missing on 35 patients, mostly children and uncooperative patients.

† Differences are statistically significant at $\mathrm{p}<0.001$.

Table 3 Patients with corneal disease by subdistrict of residence presenting to the district hospital (Chikwawa district)

\begin{tabular}{lccc}
\hline & $\begin{array}{l}\text { No of patients } \\
\text { with corneal } \\
\text { disease }\end{array}$ & $\begin{array}{l}\text { Per 10000 } \\
\text { population }\end{array}$ \\
\hline Subdistrict & Population & 56 & $23 \cdot 1$ \\
\hline Kasisi & 24300 & 56 & $17 \cdot 3$ \\
Katunga & 13850 & 24 & $6 \cdot 6$ \\
Maseya & 19700 & 13 & $1 \cdot 5$ \\
Lundu & 39700 & 6 & $2 \cdot 4$ \\
Makhwira & 58250 & 14 & $2 \cdot 7$ \\
Chapananga & 78950 & 21 & 3.4 \\
Ngabu & 119000 & 41 & $4 \cdot 9$ \\
Total & 353750 & 175 &
\end{tabular}

distant subdistricts (13.5 days for non-TEM users and $37 \cdot 2$ days for TEM users).

\section{Discussion}

Rural patients commonly consult traditional healers for eye disease even after receiving treatment from health staff. In Chikwawa District, and much of Malawi, traditional healers are found in almost every village and are more accessible (one healer per 350 population) than district health staff (one health staff member per 2030 people).

In contrast with reports from Tanzania, ${ }^{3}$ we found few young children presenting to rural health facilities with corneal disease. High vitamin A capsule supplementation and measles immunisation coverage have led to the virtual disappearance of vitamin $\mathrm{A}$ and measles related eye pathology in the two districts and have changed the pattern of blindness in children.

While there are some detrimental practices performed by traditional healers it should not be assumed that all practices of traditional healers are detrimental. There are three treatment modalities practised by the healers: application of plant products directly into the eye, face washes, and steam baths. Only the first of these is likely to have detrimental effects on the eye. Face washes and steam baths, by cleaning the skin of discharge around the eye, may reduce the likeli-

Table 4 Patients with corneal disease by subdistrict of residence presenting to the district hospital by traditional eye medicine (TEM) use and days to presentation (Chikwawa district)

\begin{tabular}{lll}
\hline Subdistrict & $\begin{array}{l}\text { TEM use reported } \\
\text { No/total }(\%)\end{array}$ & $\begin{array}{l}\text { Mean days to } \\
\text { presentation }\end{array}$ \\
\hline Kasisi & $17 / 56(30 \cdot 4)$ & $12 \cdot 6$ \\
Katunga & $5 / 24(20 \cdot 8)$ & $15 \cdot 5$ \\
Maseya & $6 / 13(46 \cdot 2)$ & $16 \cdot 1$ \\
Lundu & $1 / 6(16 \cdot 7)$ & $13 \cdot 5$ \\
Makhwira & $11 / 14(78 \cdot 6)$ & $37 \cdot 4$ \\
Chapananga & $11 / 21(52 \cdot 4)$ & $29 \cdot 2$ \\
Ngabu & $20 / 41(48 \cdot 8)$ & $24 \cdot 8$ \\
\hline
\end{tabular}

*Values for the subdistricts were significantly non-random $(\mathrm{p}<0.005)$. 
hood of transmission of bacterial and viral infections.

Traditional healers will continue to be consulted. Changing the beliefs of the population regarding traditional healers would require a costly, long term educational intervention and may be inappropriate given the harsh economic climate in much of Africa. Working with healers, training them to recognise cases needing urgent referral and encouraging the use of non-harmful practices, is less costly and may provide a more sustainable health care structure in the community. A recent review of training programmes established for traditional healers (none of the programmes related to eye care) showed that all of the programmes produced positive changes in attitudes, practices, or both by the healers and by the health sector staff involved. ${ }^{6}$ Increasing the trust and respect between health staff and healers could assist in reducing preventable blindness.

This study was supported by Project ORBIS and the International Eye Foundation. The authors are grateful for their support.

1 Foster A, Gilbert C. Community efforts in the reduction of corneal blindness in developing countries. Refr Corn Surg $1991 ; 7: 445-8$.

2 Foster A, Sommer A. Corneal ulceration, measles, and childhood blindness in Tanzania. Br $\mathcal{F}$ Ophthalmol 1987; 71: 331-43.

3 Yorston D, Foster A. Traditional eye medicines and corneal ulceration in Tanzania. $\mathcal{F}$ Trop Med Hyg 1994; 97: 211-4.

4 McMoli TE, Bordoh AN, Munube GMR, Bell EJ. Epidemic acute haemorrhagic conjunctivitis in Lagos, Nigeria. $\mathrm{Br} \mathcal{F}$ Ophthalmol 1984; 68: 401-4.

5 Chirambo M, Ben-Ezra D. Causes of blindness among students in blind school institutions in a developing country. $\mathrm{Br} \mathcal{F}$ Ophthalmol 1976; 60: 665-8.

6 Hoff W. Traditional healers and community health. World Health Forum 1992; 13: 182-7. 